\title{
Selecting Comparables for the Valuation of European Firms
}

\section{Ingolf Dittmann* \\ Christian Weiner*}

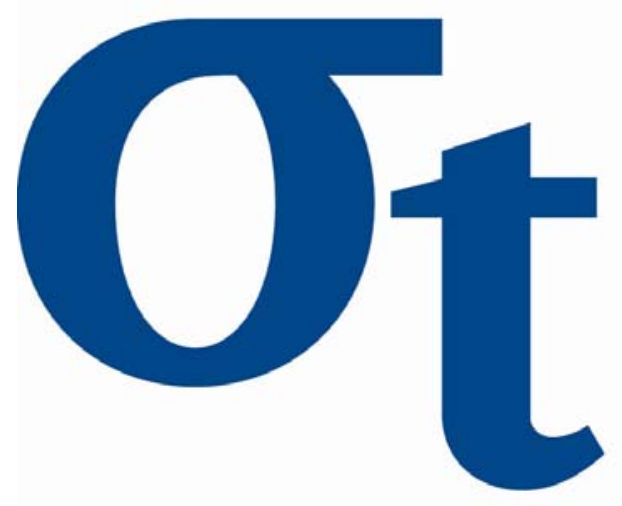

9)

寸

6

* Humboldt-Universität zu Berlin, School of Business and Economics, Germany

This research was supported by the Deutsche Forschungsgemeinschaft through the SFB 649 "Economic Risk". 


\title{
Selecting Comparables for the Valuation of European Firms ${ }^{\#}$
}

\author{
Ingolf Dittmann ${ }^{\ddagger}$ and Christian Weiner ${ }^{\ddagger}$
}

February 10, 2005

\begin{abstract}
:
This paper investigates which comparables selection method generates the most precise forecasts when valuing European companies with the enterprise value to EBIT multiple. We also consider the USA as a reference point. It turns out that selecting comparable companies with similar return on assets clearly outperforms selections according to industry membership or total assets. Moreover, we investigate whether comparables should be selected from the same country, from the same region, or from all OECD members. For most European countries, choosing comparables from the 15 European Union member states yields the best forecasts. In contrast, for the UK and the US, comparables should be chosen from the same country only.
\end{abstract}

JEL Classification Codes: G19, M41

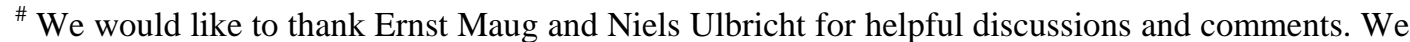
gratefully acknowledge financial support by the Rudolf von Bennigsen-Foerder foundation and by the Deutsche Forschungsgemeinschaft through the SFB 649 "Economic Risk”.

${ }^{\ddagger}$ Humboldt-Universität zu Berlin, School of Business and Economics, Spandauer Str. 1, 10178 Berlin, Germany; e-mail: dittmann@wiwi.hu-berlin.de, weiner@wiwi.hu-berlin.de
} 


\section{Introduction}

In this paper we address the question how comparables should be chosen when valuing European companies with the enterprise value to EBIT multiple. We analyze a large sample of European and US firms over 10 years and establish that for all countries forecast errors are minimized when comparable companies are chosen that are most similar in terms of return on assets to the company to be valued. For most continental European firms, comparables should be selected from all 15 European member states, whereas comparables for US or UK firms should be chosen, respectively, from the US or the UK only.

Several surveys demonstrate that practitioners frequently use financial ratios (or multiples) for the valuation of companies or projects (see Graham and Harvey, 2001, Manigart et al., 2000, and Dittmann, Maug and Kemper, 2004). The popularity of the multiple method can be attributed to its relative simplicity compared to other company valuation methods like discounted cash flow techniques. It also turns out to be surprisingly successful in comparative empirical studies by Kaplan and Ruback (1995) and Gilson, Hotchkiss and Ruback (2000).

Most empirical research on multiples valuation focuses on the optimal type of multiple and on the optimal way to average multiples across comparable firms ${ }^{1}$. Altogether, these studies establish that earnings multiples result in more accurate forecasts than multiples based on book values or sales. Multiples calculated from analysts' forecasts perform better than multiples based on historical data. Also, the harmonic mean leads to more accurate forecasts than the arithmetic mean or the median. Here, forecast accuracy is measured by the deviation of the predicted value of the firm from its market value.

On the other hand, there is only little existing research on the question how comparable companies should be selected. Alford (1992) shows for a sample of US firms that industry membership or a combination of return on equity and total assets

\footnotetext{
${ }^{1}$ The optimal type of multiple is studied by Kim and Ritter (1999), Cheng and McNamara (2000), Lie and Lie (2002), Liu, Nissim and Thomas (2002a,b), and Herrmann and Richter (2003). The optimal way to average multiples across companies is investigated by Boatsman and Baskin (1981), Beatty, Riffe and Thompson (1999), Baker and Ruback (1999), Liu, Nissim and Thomas (2002a), and Herrmann and Richter (2003).
} 
are effective criteria for selecting comparable firms. Cheng and McNamara (2000) and Bhojraj and Lee (2002) demonstrate that a combination of industry membership with total assets and further firm characteristics results in some improvements over the use of industry membership alone. All results on the optimal choice of comparables have been derived for US data only. Only Herrmann and Richter (2003) address this question with a sample that contains large American and European firms.

In this paper we compare the five selection rules proposed by Alford (1992) on a large sample of firms from 16 countries (the 15 European Union member states and the USA) over the 10 years from 1993 to 2002. This research design allows us to verify whether the results found in previous studies for the US also hold for individual European countries and whether they are stable over time. Since accounting standards and the institutional background vary from country to country, it is not obvious that there is a single comparable selection method that works best for all countries. As European countries are much smaller than the US, we also analyze what country pool the comparables should be selected from. We allow for three pools of comparables: firms from the same country, from the same region, or from all OECD countries. Here, "same region” is defined as the 15 European Union member states (EU15) or for the USA - as the NAFTA member states.

It turns out that for all countries in our study (including the US) forecast errors are minimized when firms are selected that are most similar either in terms of return on assets (ROA) or in terms of ROA and total assets. For the US, the UK, and Ireland the most accurate selection criterion is the combination of ROA and total assets. For other countries, there is no or only a marginal improvement from using total assets in addition to ROA. Moreover, we establish that comparables should be chosen from the same country for the US, the UK, Denmark and Greece. For all remaining European countries, comparables should be selected from the EU15 or from the OECD.

We do not find a clear trend of valuation errors over time. For all countries, valuation errors are unusually low in 1994 or 1995 while they show a distinct peak during the stock market boom in 1999 and 2000. In 2001 and 2002 - after the “internet bubble” had burst - valuation errors reverted to their pre-1998 level. The introduction of the euro in 1999 seems not to have had any effect on valuation errors of European firms, although our sample period is too short to give a final answer to this question. 
The paper is organized as follows. The next section presents our research design in more detail. Section 3 describes the construction of our dataset, Section 4 contains our empirical results, and Section 5 concludes. The appendix contains the definitions of all variables used in our study.

\section{Research design}

This paper focuses on the enterprise-value-to-EBIT ratio, because previous research by Liu, Nissim and Thomas (2002a, 2002b), Cheng and McNamara (2000), and Herrmann and Richter (2003) shows that using earnings as a basis for calculating multiples leads to lower forecast errors than book values or sales. Also, the research by Beatty, Riffe and Thompson (1999), Baker and Ruback (1999), and Liu, Nissim and Thomas (2002) yields that the use of the harmonic mean results in more precise forecasts than the arithmetic mean or the median. For this reason, we use the harmonic mean in this paper. Altogether, our estimate for firm i's enterprise value $\hat{E V}_{i}$ is given by

$$
\hat{E V_{i}}=\left[\frac{1}{n_{i}} \sum_{j \in C_{i}}\left(\frac{E V_{j}}{E B I T_{j}^{a d j}}\right)^{-1}\right]^{-1} \cdot E B I T_{i}^{a d j},
$$

where $E V_{j}$ is the enterprise value of firm $j, E B I T_{j}^{a d j}$ is firm $j$ 's (adjusted) earnings before interest and taxes, $C_{i}$ is the set of comparable firms used for valuing firm $i$, and $n_{i}$ is the number of firms in the set $C_{i}$. All quantities that enter equation (1) stem from a single calendar year.

When calculating the enterprise-value-to-EBIT ratio, we consider the firm's operating activities only, i.e. we calculate the numerator and the denominator net of cash and short-term investments held by the firm. The enterprise value $E V_{j}$ is therefore defined as firm $j$ 's market capitalization plus total debt minus cash and short-term investments. Correspondingly, EBIT ${ }^{a d j}$ refers to earnings before interest and taxes (EBIT) minus non-operating interest income. A more detailed description how the variables in equation (1) were constructed can be found in Appendix A.

We restrict our analysis to firms whose fiscal year ends between December $31^{\text {st }}$ and March $31^{\text {st }}$ and use market data from the end of June. We choose this range for the fiscal year end, because the most popular fiscal year end is March $31^{\text {st }}$ in Japan and December $31^{\text {st }}$ for most other OECD countries. Restricting our sample firms to 
have fiscal year end December $31^{\text {st }}$ would result in a loss of 93\% of all Japanese firms and $67 \%$ of all UK firms. In the UK, fiscal year ends are unusually evenly spread out across the whole year with peaks on December $31^{\text {st }}$, June $30^{\text {th }}$, and March $31^{\text {st }}$.

The aim of our study is to compare several different methods for determining the set $C_{i}$ of comparable firms in equation (1). Such a method consists of a pool of firms from which comparables are chosen and a rule that describes how comparables are selected from this pool. In this paper, we consider three different pools of firms: firms from the same country, firms from the same region, and firms from the 30 countries organized in the OECD. For European countries, the same region is defined as the EU15, i.e. the 15 countries that constituted the European Union until April 2004. For the USA, same region consists of the three countries (USA, Canada, Mexico) that signed the North American Free Trade Agreement (NAFTA). In all cases, the firm that is to be valued is excluded from the pool of comparable firms.

We consider five comparables selection rules that describe how the set of comparables $C_{i}$ in equation (1) is chosen from the pool of comparables. In order to facilitate the comparison of our results with the extant literature, we adopt the rules introduced by Alford (1992):

MARKET refers to the use of the entire pool of comparables. So comparable firms are either all other firms in the same country, all other firms in the same region (EU15 or NAFTA) or all other firms in the 30 OECD countries.

INDUSTRY refers to an algorithm that selects comparable companies from the same industry according to the SIC (Standard Industrial Classification) code. The algorithm selects all firms with the same 4-digit SIC code. If this results in less than five comparable firms, all firms with the same 3-digit (2-digit, 1-digit) SIC code are chosen, until there are at least five comparable firms. ${ }^{2}$ If there are less than five other firms with the same 1-digit SIC code, all firms in the pool of comparables are used. In this case, which can occur for small countries, INDUSTRY and MARKET are identical.

ROA denotes an algorithm that selects those $2 \%$ of all companies in the comparables pool whose return on assets are closest to the return on assets of the

\footnotetext{
${ }^{2}$ The choice of the number five is arbitrary and we are not aware of any study that investigates which minimum number of firms is optimal. We therefore follow the convention set by Alford (1992).
} 
considered company in absolute terms. ${ }^{3}$ If the comparables pool contains less than 250 firms, the algorithm selects the five firms that are most similar to the considered company in terms of return on assets. This ensures that there are at least five comparable firms in the set $C_{i}$.

TA refers to a similar algorithm that selects the $2 \%$ (or five) most similar firms in terms of total assets.

ROA \& TA denotes an algorithm that selects all firms in the intersection of the $14 \%$ most similar firms in terms of return on assets and the $14 \%$ most similar firms in terms of total assets. ${ }^{4}$ If this results in less than five comparable firms, the procedure is repeated with a $15 \%(16 \%, 17 \%$, etc.) cut-off, until at least five comparable firms are selected.

For comparing different comparable selection methods, we follow the literature (see e.g. Alford, 1992) and use the mean and the median of the absolute prediction error $A P E_{i}$ :

$$
A P E_{i}=\left|\frac{E V_{i}-E V_{i}}{E V_{i}}\right| .
$$

\section{Dataset}

This study combines accounting data from Worldscope and market data from Datastream. From the Worldscope database, we identify 225,783 firm-year observations of OECD firms between 1993 and 2002. We exclude a total of 80,794 firm-year observations for the following reasons: First, we require positive, nonmissing values for total assets (item 2999) and earnings before interest and taxes (item 18191), and non-negative, non-missing values for total debt (item 3255). We exclude observations with negative EBIT because the enterprise-value-to-EBIT multiple is meaningless if EBIT is negative. Second, we require that cash and short term

\footnotetext{
${ }^{3}$ Again the choice of $2 \%$ is arbitrary and, to our knowledge, has not been subject to a rigorous empirical study. We therefore follow the convention set by Alford (1992). We extend Alford's rule by demanding that at least 5 comparable firms are used. In Alford's study this additional restriction would never be binding as he works with a large US sample.

${ }^{4}$ Again, the $14 \%$ stem from Alford (1992). Note that $14 \%$ is the square root of $2 \%$, so if total assets and ROA are independently distributed, the intersection of the $14 \%$ firms most closely related in terms of total assets and the $14 \%$ firms most closely related in terms of ROA is $2 \%$ of all firms.
} 
investments (item 2001) and non-operating interest income (item 1266) are nonnegative. If either of these two items is missing, we set it equal to zero. Finally, we require that the SIC code is not missing and not equal to 9999 which denotes "nonclassifiable establishments.” If available, we use the annually reported SIC code of the largest product segment of the firm (item 19506); otherwise, we use the static SIC code of the largest product segment (item 7021).

We exclude 14,394 firm-year observations because firms had issued more than one type of common equity in that year. Moreover, we delete 27,222 observations because the fiscal year end does not fall into the period between December 31 and March 31. In addition, we lose 18,516 observations because we cannot obtain end-of-June market data from Datastream (unadjusted price, UP, and number of shares, NOSH). We then exclude 14,660 observations for which there is a mismatch between the country of incorporation (Worldscope item 6027) and the currency of the market data (Datastream item ISOCUR). Such a mismatch occurs when, according to our data, a firm is not listed on a domestic but only on a foreign stock exchange. We exclude these observations, because it is debatable what the home country of such a firm is. Requiring that the enterprise value is positive results in a further loss of 679 observations. In these cases, cash and short term investments are larger than the firm's market capitalization plus total debt. Likewise, we exclude another 809 observations, because non-operating interest income exceeds earnings before interest and taxes, so that our adjusted EBIT is negative.

Finally, we drop 1,276 observations that fall in the smallest $1 \%$ quantile of the enterprise-value-to-EBIT distribution or in the largest $1 \%$ quantile of the return on assets (ROA) distribution, where ROA is calculated as earnings before interest and taxes (item 18191) divided by total assets (item 2999). We exclude observations with the 1\% largest ROA, because these ROAs are unrealistically high and would clearly also be removed by an analyst who selects comparables by hand. Due to these exclusions, the maximum ROA is reduced from $945 \%$ to $37 \%$. Observations with the $1 \%$ smallest enterprise-value-to-EBIT multiple are excluded, because these observations receive an extremely high weight when calculating the harmonic mean. On the other hand, these observations are most likely due to exceptional circumstances that lead to disproportionately high earnings numbers. As a consequence of our exclusions, the minimum enterprise-value-to-EBIT multiple increases from 0.00007 to 1.45 . The final sample contains 67,433 firm-year 
observations from 29 of the 30 OECD countries. Our sample does not contain any Icelandic firms.

Insert Table 1 about here.

Table 1 displays the number of observations in our sample for each country and each year. It shows that there is a dramatic increase in the number of observations from 1994 to 1995, especially for European countries other than the United Kingdom. The reason is that Datastream's coverage before 1995 is acceptable only for the US, the UK and Japan. Consequently, our results for continental European firms before 1995 should be treated with care. Table 1 also demonstrates the difference in size between the individual countries' capital markets: The number of firms in the USA is consistently about twice the combined number of firms in the three largest European markets (UK, France and Germany).

Our sample does not overlap with either Alford's (1992) or Cheng and McNamara's (2000) sample. There is a considerable overlap with Bhojraj and Lee’s (2002) sample, however. For 1998, for example, our sample contains more than twice as many US observations than their sample does.

Insert Table 2 about here.

Table 2 shows some descriptive statistics for the main variables used in our analysis. The values have been pooled across all countries and years, and all currencies have been converted to US\$. The average enterprise value is $\$ 4.1 \mathrm{bn}$ and the median enterprise value is $\$ 305 \mathrm{~m}$. The median return on assets is $7.7 \%$ and the median enterprise-value-to-EBIT-ratio is 12.75 . The arithmetic mean of this ratio (48.0) is much larger than the median due to some large positive observations that are caused by small earnings numbers. Note that these do not cause any problems in our analysis, because they receive extremely small weights when we calculate the harmonic mean. In terms of total assets, the firms in our sample are of similar size to the firms in Alford (1992) but smaller than those considered by Cheng and McNamara (1999). 


\section{Empirical results}

Recall that a comparable selection method is a combination of a pool of firms from which comparables are chosen and a rule that describes how comparables are selected from this pool. In this study, we consider three comparable pools (country, region, OECD) and five comparable selection rules (MARKET, INDUSTRY, TA, ROA, and ROA \& TA), i.e. a total of 15 comparables selection methods. For each combination of the 16 countries (the 15 European Union member states and the USA), the 10 years (from 1993 to 2002), and the 15 comparables selection methods, we obtain a sample of the absolute prediction errors from equation (2) for all firms in that country-year. In Subsections 4.1 and 4.2, we pool these prediction errors across years, in order to identify the optimal comparable selection method for each individual country. These results have the highest practical relevance as they directly imply how firms should be valued. In Subsection 4.3, we pool the prediction errors across countries in order to study the stability of our results over time.

\subsection{Comparable selection rules and valuation errors}

Table 3 presents mean and median absolute prediction errors for 16 countries and 15 comparables selection methods. Here, we have pooled the prediction errors across the four years from 1999 to 2002 in order to obtain more stable results. We do not pool the prediction errors across the full 10 year range of our sample, because the introduction of the Euro in January 1999 might have changed the degree of market integration in Europe. The last two columns of Table 3 display p-values of the paired two-sample Wilcoxon signed rank test. Here we test whether the median absolute prediction error differs significantly between "Country” and "Region” (second-to-last column of Table 3) or between "Country" and "OECD” (right-most column of Table $3)$.

Table 4 summarizes the statistical evidence on the relative accuracy of different comparable selection rules. It shows p-values of three paired two-sample tests for equal location of the two distributions: the t-test, the Wilcoxon signed rank test and the sign test. The left panel of Table 4 compares ROA with ROA \& TA. As we consider three comparable pools (country, region, OECD), there are actually three ROA samples and three ROA \& TA samples that could be compared with one another. In order to reduce the comparison to a single p-value, we choose the ROA \& 
TA sample that leads to the smallest median absolute prediction error and compare this to each of the three ROA samples which results in three p-values for each test. Table 4 reports only the largest of these three p-values. The middle panel of Table 4 compares ROA \& TA with INDUSTRY and MARKET. Again we choose the ROA \& TA sample with the smallest median absolute prediction error and compare this to each of the six INDUSTRY or MARKET samples, so that we get six p-values for each test. Only the largest p-value is reported in Table 4. Likewise, the right panel of Table 4 contains the results of the comparison of ROA with INDUSTRY and MARKET.

Insert Tables 3 and 4 about here.

The most striking result from Table 3 is that both measures of forecast accuracy, (the mean and the median absolute prediction error) are smallest for either ROA or ROA \& TA for all 16 countries. The only exception to this rule is the median absolute error for Sweden which is smallest when all OECD firms are used as comparables (i.e. for MARKET). For Sweden, none of the tests shown in Table 4 finds a significant difference between the selection rules. For eleven of the remaining countries (Austria, Belgium, Denmark, France, Germany, Ireland, Italy, Portugal, Spain, the UK and the USA), however, either ROA or ROA \& TA is significantly better than MARKET and INDUSTRY according to the Wilcoxon test. For Finland, Greece, Luxembourg, and the Netherlands, the improvement of ROA or ROA \& TA is not significant.

On average, comparables with similar ROA and total assets lead to smaller prediction errors than comparables with similar ROA only. For about two thirds of the countries in our sample, ROA \& TA outperforms ROA. For the US, the UK and Ireland, ROA \& TA is clearly and significantly better than ROA. For the remaining countries, however, the improvement is generally small and insignificant. The by far worst selection rule is to choose firms with similar total assets only. For most countries, this rule is even dominated by MARKET, i.e. by using all firms in the comparables pool.

Only for Italy, choosing firms from the same industry is unambiguously better than taking firms from the whole market. When precision is judged by the median absolute error, INDUSTRY also leads to improvements in France, Ireland, the UK and the US. 
For the mean absolute error, however, INDUSTRY is only slightly better or even worse than MARKET in these countries. In contrast, for a couple of smaller countries (Austria, Belgium, Denmark, Greece, and Portugal) INDUSTRY is dominated by MARKET - even when comparables are chosen from the larger EU15 or OECD pool. This finding suggests that, in smaller countries, either firms are misclassified more often or firm value does not vary much across industries.

Like Alford (1992), we find that INDUSTRY leads to lower median absolute errors in the USA than MARKET does. However, the improvement is much smaller in our sample than in Alford's sample. Also, ROA and ROA \& TA are a much stronger improvement in our sample than in Alford's sample. The reason for this difference is presumably that Alford considers the P/E ratio, whereas we work with the enterprise-value-to-EBIT multiple, which is less sensitive to differences in leverage across firms. As leverage varies considerably between industries, controlling for industry should be more effective for the P/E ratio than for the enterprise-value-toEBIT ratio.

\subsection{What pool should comparables be selected from?}

Table 3 reveals that there are only four countries (the UK, the US, Denmark and Greece) for which valuation errors are minimized when comparables are chosen from the same country. For the remaining twelve European countries, valuation errors are smaller when comparables are chosen from the EU15 or from the OECD. According to the median absolute error, EU15 is optimal for eight countries (Belgium, Finland, France, Germany, Italy, the Netherlands, Portugal, and Spain) whereas OECD is optimal for four countries (Austria, Ireland, Luxembourg, and Sweden). When the mean absolute error is considered the relevant measure of accuracy, EU15 is optimal only for Italy. For the remaining eleven European countries, OECD is then optimal.

The reason for the differences between median and mean absolute errors are outliers that are more likely in small samples (EU15) than in large samples (OECD). Consider for example Germany: The $99^{\text {th }}$ percentile of the absolute error is 4.66 when comparables are chosen from the EU15 compared to 3.76 when they are chosen from OECD countries. If the user cannot identify such severe misvaluations, she should therefore select comparables from the larger sample (OECD). If on the other hand the user is able to identify and avoid these misvaluations, the median absolute error seems 
to be the more appropriate measure of accuracy and she should therefore chose comparables from the EU15 countries.

One could argue that the organization of capital markets in the United Kingdom is more similar to that of the United States than to continental Europe. We therefore also considered the union of NAFTA and the UK as a pool for choosing comparables for UK firms. It turns out that this Anglo-American comparables pool leads to very similar prediction errors as the EU15 pool. In particular, it does not dominate selecting comparables from the UK only. We therefore do not report these results in more detail.

\subsection{Valuation errors over time}

Table 5 contains the mean and median absolute errors for each year from 1993 to 2002 and for 12 multiple selection methods. In order to conserve space, we do not report results for total assets (TA) any longer as TA is clearly dominated by the other selection rules. Panel A displays the results for the USA, and Panel B for the UK. Panel $\mathrm{C}$ shows the results for the pooled absolute prediction errors of the remaining 14 European countries.

Insert Table 5 and Figures 1 to 3 about here.

The precision of the individual methods over time is plotted in Figure 1 for the US, in Figure 2 for the UK and in Figure 3 for the EU15 without the UK. The figures demonstrate that ROA \& TA leads to the lowest valuation errors in the UK and the US, at least since 1996. Before 1996 and over all years for continental European countries, there is no clear advantage of ROA \& TA over ROA. In contrast, INDUSTRY is comparatively poor - especially for continental European companies. Hence, our result that comparables should be selected according to ROA or ROA \& TA is robust over time.

The plots reveal that the valuation accuracy varies markedly over time. All plots show unusually low valuation errors in 1994 or 1995 and unusually high valuation errors during the internet bubble 1999/2000. After the bubble had burst, valuation errors seem to have reverted to their long-run mean in all countries. Hence, the internet bubble might explain the "sustained decline" of the valuation accuracy noted by Liu, Nissim and Thomas (2002b) who study a sample from 1987 to 2001. 
It is not surprising that selecting comparables according to ROA performed worse during the 1999/2000 "new economy" boom, because at that time many market participants expressed the belief that there had been a structural break, so that past performance was not regarded a good proxy for future performance any longer. What is perhaps more surprising is that also the accuracy of INDUSTRY deteriorated likewise during the "new economy" boom. This finding suggests that the SIC industry classification is not able to separate "new economy" firms from "old economy" firms. Indeed, in many industries there are old and new economy firms. Consider for example Amazon, whose SIC code is 5942 (Book Stores), or e-bay with the SIC code 5961 (Catalog \& Mail-Order Houses).

Our finding that comparables for the UK or the US should be selected from the same country turns out to be reasonably robust over time. According to the median absolute error, the optimal comparables pool from 1995 onwards is the UK for the UK and the US or NAFTA for the US. In the early years 1993 and 1994, OECD is optimal for both, the UK and the US, presumably because of the comparatively small sample size. For continental European countries, the optimal pool is not stable over time before 2000. Over the last three years in our sample (2000-2002), we obtain the same result as in Subsection 4.2: EU15 is optimal when judged by the median absolute prediction error and OECD is optimal when judged by the mean absolute prediction error.

\section{Conclusions}

In this paper, we investigate which comparables selection method leads to the most precise forecasts when using the enterprise value to EBIT multiple. As accounting standards and the organization of capital markets differ considerably between countries and over time, we separately consider 15 European countries and the USA over the ten years from 1993 to 2002. We work with a comprehensive sample with 67,433 firm-year observations.

Our analysis yields two principal results that are relevant for the valuation of firms in practice: First, choosing comparables from the same industry (as proxied by the SIC code) turns out to be suboptimal for all countries. Instead, those firms should be used as comparables that are most similar in terms of return on asset (ROA). For the 
USA, the UK and Ireland, this selection method can be further improved by selecting firms that are most similar according to ROA and total assets.

Second, our analysis reveals that comparables for the USA, the UK, Denmark, and Greece should be chosen from the same country only. For all remaining European countries, forecasts are more precise when firms are chosen from the 15 European union member states (EU15) or from the 30 countries organized in the OECD. Whether EU15 or OECD should be used as the comparable pool depends on the ability of the user to identify and thereby to avoid extreme valuation errors of $300 \%$ and higher. The user might be able to avoid extreme errors when she has additional information - beyond the information used in our study - about the firm to be valued or about the comparable firms selected by our algorithm. If the user is not able to avoid extreme errors, she should select comparables from the OECD. Then the larger number of comparables make extreme errors less likely. On the other hand, if the user can avoid extreme errors, she should choose comparables from the EU15.

\section{Appendix A: Definition of variables}

Market capitalization is the product of the number of shares outstanding (Datastream data type NOSH) and the unadjusted share price (data type UP) on the last trading day in June.

Enterprise value $E V_{j}$ is firm $j$ 's market capitalization plus total debt (Worldscope item 3255) minus cash and short-term investments (item 2001).

Adjusted earnings before interest and taxes $E B I T^{\text {adj }}$ is Worldscope item 18191 (earnings before interest and taxes) minus item 1266 (non-operating interest income). Enterprise-value-to-EBIT ratio is the enterprise value $E V_{j}$ divided by adjusted earnings before interest and taxes $E B I T^{a d j}$.

Total assets TA is Worldscope item 2999.

Return on assets $R O A$ is the ratio of Worldscope item 18191 (earnings before interest and taxes) and item 2999 (total assets).

SIC Code: If available, we use the annually reported SIC code of the largest product segment of the firm (item 19506); otherwise, we use the static (current) SIC code of the largest product segment (item 7021). 


\section{References}

Alford, Andrew W. (1992): "The effect of the set of comparable firms on the accuracy of the price-earnings valuation method”, Journal of Accounting Research 30, 94108.

Baker, Malcolm and Richard S. Ruback (1999): "Estimating industry multiples”, working paper Harvard University.

Beatty, Randolph P., Susan M. Riffe and Rex Thompson (1999): “The method of comparables and tax court valuations of private firms: An empirical investigation”, Accounting Horizons, 13, 177-199.

Bhojraj, Sanjeev and Charles M. C. Lee (2002): "Who is my peer? A valuation-based approach to the selection of comparable firms”, Journal of Accounting Research 40, 407-439.

Boatsman, J. and E. Baskin (1981): “Asset valuation with incomplete markets”, The Accounting Review 56, 38-53.

Cheng, C. S. Agnes and Ray McNamara (2000): “The valuation accuracy of the priceearnings and price-book benchmark valuation methods”, Review of Quantitative Finance and Accounting 15, 349-370.

Dittmann, Ingolf, Ernst Maug and Johannes Kemper (2004): "How fundamental are fundamental values? Valuation methods and their impact on the performance of German venture capitalists”, forthcoming: European Financial Management.

Gilson, S.C., E.S. Hotchkiss and R.S. Ruback (2000): "Valuation of bankrupt firms”, Review of Financial Studies 13, 43-74.

Graham, John R. and Campbell R. Harvey (2001): “The theory and practice of corporate finance: Evidence from the field”, Journal of Financial Economics 60, 187-243.

Herrmann, Volker and Frank Richter (2003): “Pricing with performance-controlled multiples”, Schmalenbach Business Review 55, 194-219.

Kaplan, Steven N. and Richard S. Ruback (1995): “The valuation of cash flow forecasts: An empirical analysis”, The Journal of Finance 50, 1059-1093.

Kim, Moonchul and Jay R. Ritter (1999): "Valuing IPOs”, Journal of Financial Economics 53, 409-437. 
Lie, Erik and Heidi J. Lie (2002): "Multiples used to estimate corporate value", Financial Analysts Journal, 58, 44-54.

Liu, Jing, Doron Nissim and Jacob Thomas (2002a): "Equity valuation using multiples”, Journal of Accounting Research 40, 135-172.

Liu, Jing, Doron Nissim and Jacob Thomas (2002b): “International equity valuation using multiples”, working paper University of California at Los Angeles.

Manigart, Sophie, Koen De Waele, Mike Wright, Ken Robbie, Philippe Desbrières, Harry Sapienza and Amy Beekman (2000): "Venture capitalists, investment appraisal and accounting information: comparative study of the USA, UK, France, Belgium and Holland”, European Financial Management 6, 389-403. 


\section{Table 1: Number of observations by firm-year}

This table displays the annual number of observations in our sample for the 15 European Union member countries, the USA, Japan, and the group of remaining OECD countries (“rem. OECD”).

\begin{tabular}{lcccccccccc}
\hline Country & $\mathbf{1 9 9 3}$ & $\mathbf{1 9 9 4}$ & $\mathbf{1 9 9 5}$ & $\mathbf{1 9 9 6}$ & $\mathbf{1 9 9 7}$ & $\mathbf{1 9 9 8}$ & $\mathbf{1 9 9 9}$ & $\mathbf{2 0 0 0}$ & $\mathbf{2 0 0 1}$ & $\mathbf{2 0 0 2}$ \\
\hline Austria & 1 & 1 & 28 & 35 & 38 & 45 & 45 & 45 & 46 & 43 \\
Belgium & 0 & 0 & 28 & 30 & 29 & 40 & 42 & 55 & 61 & 55 \\
Denmark & 0 & 0 & 48 & 55 & 60 & 80 & 83 & 82 & 75 & 72 \\
Finland & 2 & 2 & 10 & 20 & 22 & 30 & 38 & 43 & 47 & 47 \\
France & 10 & 10 & 327 & 333 & 329 & 421 & 458 & 476 & 457 & 441 \\
Germany & 4 & 6 & 195 & 211 & 199 & 255 & 289 & 317 & 316 & 313 \\
Greece & 0 & 0 & 36 & 52 & 50 & 86 & 89 & 97 & 130 & 146 \\
Ireland & 8 & 8 & 27 & 27 & 27 & 28 & 29 & 28 & 30 & 25 \\
Italy & 1 & 0 & 58 & 65 & 74 & 85 & 100 & 104 & 117 & 129 \\
Luxembourg & 0 & 2 & 6 & 6 & 6 & 8 & 11 & 8 & 9 & 13 \\
Netherlands & 8 & 8 & 126 & 130 & 135 & 152 & 167 & 154 & 131 & 116 \\
Portugal & 0 & 0 & 27 & 33 & 33 & 62 & 57 & 52 & 49 & 35 \\
Spain & 0 & 0 & 79 & 92 & 91 & 105 & 114 & 122 & 116 & 119 \\
Sweden & 0 & 0 & 18 & 27 & 29 & 51 & 62 & 59 & 50 & 65 \\
UK & 331 & 328 & 704 & 796 & 835 & 862 & 787 & 670 & 662 & 626 \\
USA & 303 & 402 & 1937 & 2583 & 2840 & 3112 & 3091 & 3004 & 2934 & 2711 \\
Japan & 1599 & 1656 & 1877 & 1968 & 2048 & 2327 & 2139 & 2170 & 2244 & 2065 \\
rem. OECD & 54 & 89 & 508 & 571 & 657 & 756 & 807 & 928 & 1099 & 1104 \\
\hline
\end{tabular}

\section{Table 2: Descriptive statistics}

This table shows mean, median, minimum, and maximum of six key variables in our dataset. The enterprise value is market capitalization plus total debt minus cash and short-term investments. Adjusted EBIT is EBIT minus non-operating interest income. The enterprise-value-to-EBIT ratio is enterprise value divided by adjusted EBIT. Return on assets is the ratio of EBIT and total assets. Note that the enterprise value is not directly comparable with total assets, because total assets include more than just the sum of common equity and total debt, and because cash and short-term investments have been subtracted from enterprise value. We therefore also report the market-to-book ratio where the numerator is total assets minus book value of common equity plus market value of common equity and the denominator is total assets.

\begin{tabular}{lrrrr}
\hline \multicolumn{1}{c}{ Variable } & \multicolumn{1}{c}{ Mean } & Median & Minimum & \multicolumn{1}{c}{ Maximum } \\
\hline Enterprise value (mill. \$) & $4,117.700$ & 305.372 & 0.326 & $835,772.750$ \\
Total assets (mill. \$) & $5,506.920$ & 356.555 & 1.031 & $1,051,450.000$ \\
EBIT (mill. \$) & 270.908 & 23.994 & 0.001 & $49,371.000$ \\
Adjusted EBIT (mill. \$) & 258.806 & 22.540 & 0.001 & $49,371.000$ \\
Enterprise-value-to-EBIT ratio & 48.010 & 12.754 & 1.448 & $325,624.830$ \\
Return on assets & 0.090 & 0.077 & 0.000 & 0.374 \\
Market-to-book ratio & 1.851 & 1.232 & 0.116 & $1,307.010$ \\
\hline
\end{tabular}




\section{Table 3: Absolute prediction errors across countries (1999-2002)}

This table displays the mean and median absolute prediction error for 15 comparables selection methods for each of the 16 countries in our study. A selection method consists of a comparable pool (country, region, or OECD) and a selection rule (Market, Industry, TA, ROA, ROA \& TA). 'Country' refers to comparables from the same country, and 'Region' to comparables from the same geographical region, i.e. from the EU15 for European countries and from NAFTA for the USA. Absolute prediction errors were calculated independently for each of the four years from 1999 to 2002. Then absolute prediction errors were pooled across these four years and the mean and median shown in the table were calculated. The number of firm-year observations is given below the country name. The rightmost two columns display the p-values of the paired two-sample Wilcoxon signed rank test for equal median error. For each country and each selection rule, it compares Country with Region, and, respectively, Country with OECD.

\begin{tabular}{|c|c|c|c|c|c|c|c|c|c|}
\hline \multirow{2}{*}{$\begin{array}{l}\text { Country } \\
\text { (\# obs.) }\end{array}$} & \multirow[t]{2}{*}{ Type } & \multicolumn{2}{|c|}{ Country } & \multicolumn{2}{|c|}{ Region } & \multicolumn{2}{|c|}{ OECD } & \multicolumn{2}{|c|}{$\begin{array}{l}\text { Wilcoxon: } \\
\text { Country vs. }\end{array}$} \\
\hline & & Mean & Median & Mean & Median & Mean & Median & Region & OECD \\
\hline Austria & Market & 0.544 & 0.416 & 0.608 & 0.438 & 0.603 & 0.424 & 0.097 & 0.038 \\
\hline \multirow[t]{4}{*}{179} & Industry & 0.609 & 0.422 & 0.644 & 0.499 & 0.639 & 0.479 & 0.659 & 0.573 \\
\hline & TA & 0.644 & 0.423 & 0.605 & 0.478 & 0.620 & 0.496 & 0.824 & 0.469 \\
\hline & ROA & 0.529 & 0.338 & 0.514 & 0.330 & 0.464 & 0.319 & 0.468 & 0.136 \\
\hline & ROA\&TA & 0.518 & 0.361 & 0.492 & 0.337 & 0.504 & 0.358 & 0.108 & 0.763 \\
\hline Belgium & Market & 0.639 & 0.494 & 0.732 & 0.478 & 0.735 & 0.469 & 0.058 & 0.267 \\
\hline \multirow[t]{4}{*}{213} & Industry & 0.667 & 0.526 & 0.750 & 0.519 & 0.748 & 0.497 & 0.377 & 0.975 \\
\hline & $\mathrm{TA}$ & 0.723 & 0.495 & 0.734 & 0.477 & 0.721 & 0.462 & 0.565 & 0.935 \\
\hline & ROA & 0.658 & 0.443 & 0.649 & 0.362 & 0.625 & 0.407 & 0.250 & 0.470 \\
\hline & ROA\&TA & 0.744 & 0.444 & 0.641 & 0.389 & 0.635 & 0.443 & 0.002 & 0.258 \\
\hline Denmark & Market & 0.487 & 0.361 & 0.483 & 0.344 & 0.488 & 0.351 & 0.090 & 0.360 \\
\hline \multirow[t]{4}{*}{312} & Industry & 0.537 & 0.415 & 0.626 & 0.493 & 0.597 & 0.443 & 0.000 & 0.004 \\
\hline & $\mathrm{TA}$ & 0.573 & 0.381 & 0.489 & 0.340 & 0.470 & 0.356 & 0.002 & 0.003 \\
\hline & ROA & 0.440 & 0.348 & 0.737 & 0.512 & 0.573 & 0.413 & 0.000 & 0.000 \\
\hline & ROA\&TA & 0.434 & 0.302 & 0.727 & 0.536 & 0.549 & 0.388 & 0.000 & 0.128 \\
\hline Finland & Market & 0.485 & 0.356 & 0.497 & 0.353 & 0.503 & 0.369 & 0.777 & 0.882 \\
\hline \multirow[t]{4}{*}{175} & Industry & 0.520 & 0.404 & 0.486 & 0.337 & 0.477 & 0.348 & 0.053 & 0.043 \\
\hline & $\mathrm{TA}$ & 0.530 & 0.369 & 0.521 & 0.369 & 0.511 & 0.385 & 0.590 & 0.271 \\
\hline & ROA & 0.426 & 0.347 & 0.391 & 0.310 & 0.386 & 0.316 & 0.734 & 0.948 \\
\hline & ROA\&TA & 0.447 & 0.343 & 0.403 & 0.302 & 0.407 & 0.332 & 0.170 & 0.626 \\
\hline France & Market & 0.580 & 0.460 & 0.609 & 0.453 & 0.609 & 0.457 & 0.000 & 0.260 \\
\hline \multirow{4}{*}{1832} & Industry & 0.601 & 0.429 & 0.609 & 0.430 & 0.614 & 0.432 & 0.279 & 0.132 \\
\hline & $\mathrm{TA}$ & 0.645 & 0.483 & 0.618 & 0.456 & 0.597 & 0.464 & 0.000 & 0.000 \\
\hline & ROA & 0.577 & 0.425 & 0.567 & 0.405 & 0.532 & 0.417 & 0.000 & 0.000 \\
\hline & ROA\&TA & 0.586 & 0.427 & 0.560 & 0.393 & 0.530 & 0.409 & 0.000 & 0.000 \\
\hline Germany & Market & 0.613 & 0.474 & 0.608 & 0.473 & 0.602 & 0.480 & 0.632 & 0.056 \\
\hline \multirow[t]{4}{*}{1235} & Industry & 0.663 & 0.466 & 0.637 & 0.475 & 0.618 & 0.468 & 0.791 & 0.286 \\
\hline & $\mathrm{TA}$ & 0.759 & 0.515 & 0.623 & 0.473 & 0.604 & 0.485 & 0.005 & 0.014 \\
\hline & ROA & 0.716 & 0.473 & 0.622 & 0.412 & 0.575 & 0.435 & 0.000 & 0.001 \\
\hline & ROA\&TA & 0.620 & 0.457 & 0.559 & 0.414 & 0.548 & 0.434 & 0.000 & 0.073 \\
\hline Greece & Market & 0.528 & 0.403 & 0.555 & 0.513 & 0.546 & 0.498 & 0.000 & 0.000 \\
\hline \multirow[t]{4}{*}{462} & Industry & 0.527 & 0.441 & 0.600 & 0.551 & 0.577 & 0.535 & 0.000 & 0.000 \\
\hline & $\mathrm{TA}$ & 0.622 & 0.458 & 0.567 & 0.535 & 0.563 & 0.542 & 0.064 & 0.010 \\
\hline & ROA & 0.522 & 0.381 & 0.517 & 0.503 & 0.530 & 0.522 & 0.000 & 0.000 \\
\hline & ROA\&TA & 0.507 & 0.367 & 0.518 & 0.521 & 0.541 & 0.561 & 0.000 & 0.000 \\
\hline
\end{tabular}




\begin{tabular}{|c|c|c|c|c|c|c|c|c|c|}
\hline \multirow{2}{*}{$\begin{array}{l}\text { Country } \\
\text { (\# obs.) }\end{array}$} & \multirow[t]{2}{*}{ Type } & \multicolumn{2}{|c|}{ Country } & \multicolumn{2}{|c|}{ Region } & \multicolumn{2}{|c|}{ OECD } & \multicolumn{2}{|c|}{$\begin{array}{l}\text { Wilcoxon: } \\
\text { Country vs. }\end{array}$} \\
\hline & & Mean & Median & Mean & Median & Mean & Median & Region & OECD \\
\hline Ireland & Market & 0.473 & 0.394 & 0.472 & 0.397 & 0.478 & 0.400 & 0.212 & 0.181 \\
\hline \multirow[t]{4}{*}{112} & Industry & 0.489 & 0.387 & 0.432 & 0.304 & 0.479 & 0.354 & 0.104 & 0.248 \\
\hline & $\mathrm{TA}$ & 0.429 & 0.321 & 0.459 & 0.379 & 0.432 & 0.348 & 0.693 & 0.740 \\
\hline & ROA & 0.481 & 0.321 & 0.389 & 0.314 & 0.371 & 0.315 & 0.038 & 0.141 \\
\hline & ROA\&TA & 0.389 & 0.303 & 0.371 & 0.276 & 0.353 & 0.254 & 0.374 & 0.259 \\
\hline Italy & Market & 0.583 & 0.496 & 0.527 & 0.501 & 0.534 & 0.521 & 0.493 & 0.032 \\
\hline \multirow[t]{4}{*}{450} & Industry & 0.512 & 0.381 & 0.497 & 0.449 & 0.507 & 0.456 & 0.119 & 0.006 \\
\hline & $\mathrm{TA}$ & 0.612 & 0.460 & 0.524 & 0.472 & 0.520 & 0.462 & 0.808 & 0.953 \\
\hline & ROA & 0.528 & 0.375 & 0.465 & 0.338 & 0.470 & 0.417 & 0.086 & 0.206 \\
\hline & ROA\&TA & 0.517 & 0.363 & 0.460 & 0.355 & 0.470 & 0.385 & 0.034 & 0.632 \\
\hline \multirow{5}{*}{$\begin{array}{c}\text { Luxembourg } \\
41\end{array}$} & Market & 0.848 & 0.589 & 0.745 & 0.562 & 0.763 & 0.574 & 0.140 & 0.215 \\
\hline & Industry & 0.851 & 0.639 & 0.728 & 0.570 & 0.731 & 0.521 & 0.503 & 0.651 \\
\hline & $\mathrm{TA}$ & 0.861 & 0.628 & 0.735 & 0.436 & 0.768 & 0.484 & 0.285 & 0.755 \\
\hline & ROA & 1.143 & 0.618 & 0.732 & 0.421 & 0.708 & 0.408 & 0.000 & 0.000 \\
\hline & ROA\&TA & 0.922 & 0.617 & 0.814 & 0.418 & 0.691 & 0.438 & 0.235 & 0.107 \\
\hline \multirow{5}{*}{$\begin{array}{c}\text { Netherlands } \\
568\end{array}$} & Market & 0.479 & 0.377 & 0.517 & 0.389 & 0.520 & 0.376 & 0.000 & 0.158 \\
\hline & Industry & 0.480 & 0.353 & 0.501 & 0.345 & 0.497 & 0.374 & 0.735 & 0.471 \\
\hline & $\mathrm{TA}$ & 0.564 & 0.418 & 0.530 & 0.398 & 0.529 & 0.392 & 0.027 & 0.008 \\
\hline & ROA & 0.495 & 0.365 & 0.440 & 0.347 & 0.426 & 0.347 & 0.064 & 0.310 \\
\hline & ROA\&TA & 0.476 & 0.378 & 0.434 & 0.333 & 0.432 & 0.348 & 0.001 & 0.028 \\
\hline \multirow{5}{*}{$\begin{array}{c}\text { Portugal } \\
193\end{array}$} & Market & 0.604 & 0.446 & 0.605 & 0.405 & 0.607 & 0.401 & 0.000 & 0.216 \\
\hline & Industry & 0.629 & 0.482 & 0.684 & 0.428 & 0.643 & 0.437 & 0.617 & 0.947 \\
\hline & $\mathrm{TA}$ & 0.617 & 0.470 & 0.598 & 0.399 & 0.564 & 0.431 & 0.210 & 0.028 \\
\hline & ROA & 0.607 & 0.410 & 0.605 & 0.342 & 0.548 & 0.378 & 0.087 & 0.029 \\
\hline & ROA\&TA & 0.523 & 0.345 & 0.628 & 0.323 & 0.571 & 0.368 & 0.667 & 0.617 \\
\hline Spain & Market & 0.516 & 0.396 & 0.506 & 0.394 & 0.502 & 0.397 & 0.534 & 0.562 \\
\hline \multirow[t]{4}{*}{471} & Industry & 0.529 & 0.374 & 0.508 & 0.400 & 0.495 & 0.388 & 0.595 & 0.565 \\
\hline & $\mathrm{TA}$ & 0.578 & 0.444 & 0.500 & 0.385 & 0.484 & 0.381 & 0.000 & 0.000 \\
\hline & ROA & 0.550 & 0.392 & 0.482 & 0.353 & 0.454 & 0.390 & 0.001 & 0.008 \\
\hline & ROA\&TA & 0.514 & 0.357 & 0.488 & 0.353 & 0.461 & 0.368 & 0.416 & 0.326 \\
\hline Sweden & Market & 0.521 & 0.376 & 0.475 & 0.351 & 0.472 & 0.331 & 0.132 & 0.079 \\
\hline \multirow[t]{4}{*}{236} & Industry & 0.530 & 0.378 & 0.455 & 0.346 & 0.460 & 0.334 & 0.410 & 0.983 \\
\hline & $\mathrm{TA}$ & 0.553 & 0.440 & 0.483 & 0.341 & 0.458 & 0.348 & 0.130 & 0.043 \\
\hline & ROA & 0.546 & 0.381 & 0.463 & 0.367 & 0.438 & 0.340 & 0.953 & 0.926 \\
\hline & ROA\&TA & 0.535 & 0.385 & 0.435 & 0.341 & 0.430 & 0.369 & 0.552 & 0.598 \\
\hline United & Market & 0.568 & 0.440 & 0.560 & 0.439 & 0.565 & 0.448 & 0.000 & 0.000 \\
\hline Kingdom & Industry & 0.573 & 0.403 & 0.565 & 0.399 & 0.555 & 0.412 & 0.868 & 0.438 \\
\hline \multirow[t]{3}{*}{2745} & $\mathrm{TA}$ & 0.597 & 0.458 & 0.559 & 0.447 & 0.549 & 0.453 & 0.013 & 0.044 \\
\hline & ROA & 0.507 & 0.356 & 0.487 & 0.373 & 0.485 & 0.404 & 0.009 & 0.000 \\
\hline & ROA\&TA & 0.479 & 0.330 & 0.479 & 0.368 & 0.475 & 0.390 & 0.000 & 0.000 \\
\hline \multirow{5}{*}{$\begin{array}{c}\text { United States } \\
11740\end{array}$} & s Market & 0.496 & 0.353 & 0.493 & 0.355 & 0.488 & 0.364 & 0.000 & 0.000 \\
\hline & Industry & 0.495 & 0.334 & 0.492 & 0.335 & 0.497 & 0.346 & 0.488 & 0.001 \\
\hline & $\mathrm{TA}$ & 0.494 & 0.346 & 0.491 & 0.347 & 0.493 & 0.348 & 0.009 & 0.336 \\
\hline & ROA & 0.453 & 0.325 & 0.451 & 0.323 & 0.464 & 0.360 & 0.373 & 0.000 \\
\hline & ROA\&TA & 0.437 & 0.306 & 0.435 & 0.307 & 0.449 & 0.329 & 0.898 & 0.000 \\
\hline
\end{tabular}




\section{Table 4: Comparison of different comparables selection rules}

This table displays p-values of the paired two-sample t-test, the paired two-sample Wilcoxon signed rank test, and the sign test for three comparisons: ROA\&TA with ROA, ROA\&TA with INDUSTRY, and ROA with INDUSTRY. For the comparison of ROA \& TA with ROA, we first choose the comparables pool with the minimum median error for ROA\&TA. This sample is then compared with all three ROA samples (Country, Region, OECD), so that we get three p-values for each test. The table displays the maximum of these three pvalues. In the middle and the right-hand panel we compare the most successful ROA\&TA (or ROA) variant with all variants of INDUSTRY and MARKET which yields six p-values for each test. Again the table only displays the maximum p-value.

\begin{tabular}{|c|c|c|c|c|c|c|c|c|c|}
\hline \multirow{2}{*}{ Country } & \multicolumn{3}{|c|}{ ROA\&TA vs. ROA } & \multicolumn{3}{|c|}{ ROA\&TA vs. INDUSTRY } & \multicolumn{3}{|c|}{ ROA vs. INDUSTRY } \\
\hline & T test & Wilcox. & Sign & T test & Wilcox. & Sign & T test & Wilcox. & Sign \\
\hline Austria & 0.355 & 0.912 & 0.765 & 0.090 & 0.000 & 0.000 & 0.011 & 0.000 & 0.000 \\
\hline Belgium & 0.701 & 0.470 & 0.337 & 0.947 & 0.001 & 0.004 & 0.753 & 0.003 & 0.009 \\
\hline Denmark & 0.769 & 0.884 & 0.692 & 0.014 & 0.028 & 0.100 & 0.067 & 0.113 & 0.610 \\
\hline Finland & 0.459 & 0.769 & 1.000 & 0.011 & 0.184 & 1.000 & 0.003 & 0.064 & 0.450 \\
\hline France & 0.292 & 0.251 & 0.624 & 0.049 & 0.000 & 0.052 & 0.154 & 0.002 & 0.009 \\
\hline Germany & 0.182 & 0.375 & 0.864 & 0.001 & 0.000 & 0.002 & 0.897 & 0.001 & 0.088 \\
\hline Greece & 0.732 & 0.134 & 0.085 & 0.388 & 0.053 & 0.023 & 0.831 & 0.468 & 0.209 \\
\hline Ireland & 0.117 & 0.029 & 0.108 & 0.027 & 0.017 & 0.156 & 0.202 & 0.222 & 0.509 \\
\hline Italy & 0.658 & 0.262 & 0.239 & 0.062 & 0.029 & 0.120 & 0.165 & 0.004 & 0.053 \\
\hline Luxembourg & 0.083 & 0.315 & 0.755 & 0.790 & 0.579 & 0.533 & 0.794 & 0.528 & 1.000 \\
\hline Netherlands & 0.410 & 0.293 & 1.000 & 0.036 & 0.123 & 0.476 & 0.068 & 0.177 & 0.706 \\
\hline Portugal & 0.545 & 0.649 & 0.195 & 0.993 & 0.006 & 0.021 & 0.997 & 0.039 & 0.031 \\
\hline Spain & 0.496 & 0.254 & 0.269 & 0.805 & 0.202 & 0.645 & 0.621 & 0.030 & 0.580 \\
\hline Sweden & 0.797 & 0.566 & 0.397 & 0.402 & 0.865 & 0.745 & 0.451 & 0.945 & 0.474 \\
\hline United Kingdom & 0.432 & 0.000 & 0.030 & 0.000 & 0.000 & 0.000 & 0.000 & 0.000 & 0.000 \\
\hline United States & 0.000 & 0.000 & 0.000 & 0.000 & 0.000 & 0.000 & 0.000 & 0.000 & 0.000 \\
\hline
\end{tabular}


Table 5: Absolute prediction errors over time

This table displays mean and median absolute prediction errors for 12 comparables selection methods for the USA (Panel A), the United Kingdom (Panel B), and for the remaining European Union member states (Panel C). In the latter case, absolute prediction errors were calculated independently for each of the 14 countries. Then absolute prediction errors were pooled across countries and the mean and median shown in the table was calculated.

Panel A: United States

\begin{tabular}{|c|c|c|c|c|c|c|c|}
\hline \multirow{2}{*}{$\begin{array}{c}\text { Year } \\
\text { (\# obs.) }\end{array}$} & \multirow{2}{*}{ Type } & \multicolumn{2}{|c|}{ USA } & \multicolumn{2}{|c|}{ NAFTA } & \multicolumn{2}{|c|}{ OECD } \\
\hline & & Mean & Median & Mean & Median & Mean & Median \\
\hline \multirow{4}{*}{$\begin{array}{l}1993 \\
(303)\end{array}$} & Market & 0.399 & 0.288 & 0.399 & 0.289 & 0.683 & 0.520 \\
\hline & Industry & 0.426 & 0.338 & 0.442 & 0.347 & 0.738 & 0.555 \\
\hline & ROA & 0.463 & 0.324 & 0.473 & 0.333 & 0.499 & 0.287 \\
\hline & ROA \& TA & 0.421 & 0.321 & 0.427 & 0.323 & 0.487 & 0.283 \\
\hline \multirow{4}{*}{$\begin{array}{l}1994 \\
(402)\end{array}$} & Market & 0.451 & 0.325 & 0.452 & 0.327 & 0.795 & 0.561 \\
\hline & Industry & 0.491 & 0.356 & 0.495 & 0.360 & 0.801 & 0.522 \\
\hline & ROA & 0.450 & 0.317 & 0.450 & 0.323 & 0.467 & 0.293 \\
\hline & ROA \& TA & 0.433 & 0.330 & 0.436 & 0.321 & 0.492 & 0.315 \\
\hline \multirow{4}{*}{$\begin{array}{c}1995 \\
(1937)\end{array}$} & Market & 0.388 & 0.289 & 0.387 & 0.288 & 0.400 & 0.291 \\
\hline & Industry & 0.381 & 0.280 & 0.379 & 0.277 & 0.404 & 0.289 \\
\hline & ROA & 0.382 & 0.275 & 0.383 & 0.275 & 0.428 & 0.312 \\
\hline & ROA \& TA & 0.374 & 0.279 & 0.375 & 0.281 & 0.421 & 0.315 \\
\hline \multirow{4}{*}{$\begin{array}{c}1996 \\
(2583)\end{array}$} & Market & 0.460 & 0.333 & 0.458 & 0.331 & 0.488 & 0.331 \\
\hline & Industry & 0.452 & 0.314 & 0.448 & 0.313 & 0.492 & 0.326 \\
\hline & ROA & 0.451 & 0.321 & 0.450 & 0.321 & 0.500 & 0.367 \\
\hline & ROA \& TA & 0.444 & 0.316 & 0.441 & 0.321 & 0.495 & 0.361 \\
\hline \multirow{4}{*}{$\begin{array}{c}1997 \\
(2840)\end{array}$} & Market & 0.465 & 0.334 & 0.466 & 0.334 & 0.475 & 0.329 \\
\hline & Industry & 0.459 & 0.318 & 0.460 & 0.316 & 0.488 & 0.323 \\
\hline & ROA & 0.439 & 0.311 & 0.440 & 0.313 & 0.464 & 0.342 \\
\hline & ROA \& TA & 0.437 & 0.307 & 0.437 & 0.307 & 0.456 & 0.331 \\
\hline \multirow{4}{*}{$\begin{array}{c}1998 \\
(3112)\end{array}$} & Market & 0.483 & 0.344 & 0.482 & 0.345 & 0.470 & 0.356 \\
\hline & Industry & 0.465 & 0.317 & 0.462 & 0.315 & 0.456 & 0.314 \\
\hline & ROA & 0.446 & 0.304 & 0.445 & 0.303 & 0.448 & 0.347 \\
\hline & ROA \& TA & 0.441 & 0.299 & 0.441 & 0.303 & 0.442 & 0.330 \\
\hline \multirow{4}{*}{$\begin{array}{c}1999 \\
(3091)\end{array}$} & Market & 0.485 & 0.349 & 0.486 & 0.348 & 0.478 & 0.354 \\
\hline & Industry & 0.477 & 0.326 & 0.480 & 0.328 & 0.485 & 0.339 \\
\hline & ROA & 0.450 & 0.324 & 0.451 & 0.319 & 0.458 & 0.351 \\
\hline & ROA \& TA & 0.433 & 0.305 & 0.434 & 0.305 & 0.446 & 0.321 \\
\hline \multirow{4}{*}{$\begin{array}{c}2000 \\
(3004)\end{array}$} & Market & 0.531 & 0.385 & 0.528 & 0.385 & 0.529 & 0.387 \\
\hline & Industry & 0.528 & 0.362 & 0.523 & 0.360 & 0.542 & 0.367 \\
\hline & ROA & 0.482 & 0.340 & 0.480 & 0.338 & 0.492 & 0.356 \\
\hline & ROA \& TA & 0.469 & 0.328 & 0.467 & 0.327 & 0.481 & 0.347 \\
\hline \multirow{4}{*}{$\begin{array}{c}2001 \\
(2934)\end{array}$} & Market & 0.485 & 0.354 & 0.480 & 0.357 & 0.472 & 0.368 \\
\hline & Industry & 0.485 & 0.326 & 0.476 & 0.332 & 0.475 & 0.342 \\
\hline & ROA & 0.439 & 0.315 & 0.435 & 0.317 & 0.453 & 0.366 \\
\hline & ROA \& TA & 0.420 & 0.302 & 0.416 & 0.299 & 0.434 & 0.321 \\
\hline \multirow{4}{*}{$\begin{array}{c}2002 \\
(2711)\end{array}$} & Market & 0.482 & 0.324 & 0.478 & 0.329 & 0.472 & 0.352 \\
\hline & Industry & 0.491 & 0.324 & 0.489 & 0.325 & 0.483 & 0.338 \\
\hline & ROA & 0.440 & 0.322 & 0.438 & 0.325 & 0.454 & 0.370 \\
\hline & ROA \& TA & 0.424 & 0.294 & 0.421 & 0.298 & 0.435 & 0.327 \\
\hline
\end{tabular}


Panel B: United Kingdom

\begin{tabular}{|c|c|c|c|c|c|c|c|}
\hline \multirow{2}{*}{$\begin{array}{c}\text { Year } \\
\text { (\# obs.) }\end{array}$} & \multirow{2}{*}{ Type } & \multicolumn{2}{|c|}{ UK } & \multicolumn{2}{|c|}{ EU 15} & \multicolumn{2}{|c|}{ OECD } \\
\hline & & Mean & Median & Mean & Median & Mean & Median \\
\hline \multirow{4}{*}{$\begin{array}{l}1993 \\
(331)\end{array}$} & Market & 0.435 & 0.289 & 0.429 & 0.299 & 0.731 & 0.532 \\
\hline & Industry & 0.435 & 0.264 & 0.427 & 0.266 & 0.693 & 0.444 \\
\hline & ROA & 0.463 & 0.285 & 0.443 & 0.285 & 0.459 & 0.271 \\
\hline & ROA \& TA & 0.413 & 0.303 & 0.416 & 0.327 & 0.425 & 0.243 \\
\hline \multirow{4}{*}{$\begin{array}{l}1994 \\
(328)\end{array}$} & Market & 0.462 & 0.289 & 0.464 & 0.293 & 0.725 & 0.466 \\
\hline & Industry & 0.471 & 0.297 & 0.476 & 0.298 & 0.756 & 0.438 \\
\hline & ROA & 0.413 & 0.257 & 0.412 & 0.258 & 0.434 & 0.258 \\
\hline & ROA \& TA & 0.422 & 0.292 & 0.412 & 0.274 & 0.425 & 0.248 \\
\hline \multirow{4}{*}{$\begin{array}{l}1995 \\
(704)\end{array}$} & Market & 0.412 & 0.279 & 0.412 & 0.276 & 0.476 & 0.320 \\
\hline & Industry & 0.420 & 0.256 & 0.428 & 0.275 & 0.494 & 0.302 \\
\hline & ROA & 0.423 & 0.285 & 0.402 & 0.293 & 0.395 & 0.277 \\
\hline & ROA \& TA & 0.394 & 0.270 & 0.378 & 0.279 & 0.384 & 0.271 \\
\hline \multirow{4}{*}{$\begin{array}{l}1996 \\
(796)\end{array}$} & Market & 0.438 & 0.312 & 0.419 & 0.307 & 0.477 & 0.332 \\
\hline & Industry & 0.458 & 0.319 & 0.453 & 0.331 & 0.512 & 0.368 \\
\hline & ROA & 0.447 & 0.290 & 0.423 & 0.330 & 0.415 & 0.293 \\
\hline & ROA \& TA & 0.405 & 0.270 & 0.403 & 0.309 & 0.405 & 0.281 \\
\hline \multirow{4}{*}{$\begin{array}{l}1997 \\
(835)\end{array}$} & Market & 0.454 & 0.339 & 0.462 & 0.343 & 0.543 & 0.386 \\
\hline & Industry & 0.462 & 0.320 & 0.470 & 0.320 & 0.561 & 0.381 \\
\hline & ROA & 0.441 & 0.300 & 0.424 & 0.316 & 0.428 & 0.293 \\
\hline & ROA \& TA & 0.413 & 0.275 & 0.409 & 0.303 & 0.417 & 0.294 \\
\hline \multirow{4}{*}{$\begin{array}{l}1998 \\
(862)\end{array}$} & Market & 0.501 & 0.383 & 0.544 & 0.397 & 0.539 & 0.391 \\
\hline & Industry & 0.497 & 0.349 & 0.544 & 0.374 & 0.572 & 0.382 \\
\hline & ROA & 0.490 & 0.344 & 0.489 & 0.351 & 0.465 & 0.365 \\
\hline & ROA \& TA & 0.462 & 0.329 & 0.473 & 0.337 & 0.460 & 0.360 \\
\hline \multirow{4}{*}{$\begin{array}{l}1999 \\
(787)\end{array}$} & Market & 0.519 & 0.406 & 0.520 & 0.406 & 0.563 & 0.426 \\
\hline & Industry & 0.500 & 0.368 & 0.521 & 0.362 & 0.547 & 0.386 \\
\hline & ROA & 0.488 & 0.351 & 0.466 & 0.358 & 0.465 & 0.363 \\
\hline & ROA \& TA & 0.458 & 0.331 & 0.464 & 0.374 & 0.456 & 0.347 \\
\hline \multirow{4}{*}{$\begin{array}{l}2000 \\
(670)\end{array}$} & Market & 0.627 & 0.520 & 0.649 & 0.531 & 0.629 & 0.520 \\
\hline & Industry & 0.602 & 0.441 & 0.611 & 0.420 & 0.575 & 0.436 \\
\hline & ROA & 0.602 & 0.440 & 0.579 & 0.429 & 0.543 & 0.463 \\
\hline & ROA \& TA & 0.563 & 0.411 & 0.560 & 0.426 & 0.534 & 0.449 \\
\hline \multirow{4}{*}{$\begin{array}{l}2001 \\
(662)\end{array}$} & Market & 0.573 & 0.445 & 0.546 & 0.443 & 0.542 & 0.444 \\
\hline & Industry & 0.614 & 0.407 & 0.575 & 0.428 & 0.552 & 0.430 \\
\hline & ROA & 0.492 & 0.345 & 0.461 & 0.387 & 0.468 & 0.420 \\
\hline & ROA \& TA & 0.465 & 0.324 & 0.454 & 0.367 & 0.459 & 0.387 \\
\hline \multirow{4}{*}{$\begin{array}{l}2002 \\
(626)\end{array}$} & Market & 0.560 & 0.403 & 0.532 & 0.387 & 0.526 & 0.412 \\
\hline & Industry & 0.589 & 0.405 & 0.561 & 0.395 & 0.547 & 0.419 \\
\hline & ROA & 0.445 & 0.301 & 0.445 & 0.343 & 0.465 & 0.395 \\
\hline & ROA \& TA & 0.432 & 0.283 & 0.437 & 0.337 & 0.451 & 0.382 \\
\hline
\end{tabular}


Panel C: 14 European Union members except the UK

\begin{tabular}{|c|c|c|c|c|c|c|c|}
\hline \multirow{2}{*}{$\begin{array}{c}\text { Year } \\
\text { (\# obs.) }\end{array}$} & \multirow{2}{*}{ Type } & \multicolumn{2}{|c|}{ Country } & \multicolumn{2}{|c|}{ EU 15} & \multicolumn{2}{|c|}{ OECD } \\
\hline & & Mean & Median & Mean & Median & Mean & Median \\
\hline \multirow{4}{*}{$\begin{array}{c}1993 \\
(32)\end{array}$} & Market & 0.621 & 0.453 & 0.588 & 0.327 & 0.977 & 0.485 \\
\hline & Industry & 0.621 & 0.453 & 0.690 & 0.400 & 1.174 & 0.551 \\
\hline & ROA & 0.773 & 0.450 & 0.572 & 0.345 & 0.736 & 0.386 \\
\hline & ROA \& TA & 0.723 & 0.414 & 0.675 & 0.306 & 0.705 & 0.350 \\
\hline \multirow{4}{*}{$\begin{array}{c}1994 \\
(36)\end{array}$} & Market & 0.892 & 0.304 & 0.398 & 0.329 & 0.590 & 0.419 \\
\hline & Industry & 0.892 & 0.304 & 0.530 & 0.365 & 0.731 & 0.495 \\
\hline & ROA & 0.889 & 0.315 & 0.464 & 0.251 & 0.451 & 0.283 \\
\hline & ROA \& TA & 0.876 & 0.333 & 0.377 & 0.248 & 0.411 & 0.258 \\
\hline \multirow{4}{*}{$\begin{array}{c}1995 \\
(1013)\end{array}$} & Market & 0.512 & 0.350 & 0.501 & 0.344 & 0.563 & 0.377 \\
\hline & Industry & 0.530 & 0.366 & 0.516 & 0.399 & 0.576 & 0.387 \\
\hline & ROA & 0.524 & 0.359 & 0.487 & 0.339 & 0.486 & 0.321 \\
\hline & ROA \& TA & 0.485 & 0.335 & 0.476 & 0.329 & 0.483 & 0.313 \\
\hline \multirow{4}{*}{$\begin{array}{c}1996 \\
(1116)\end{array}$} & Market & 0.519 & 0.395 & 0.534 & 0.400 & 0.632 & 0.412 \\
\hline & Industry & 0.537 & 0.401 & 0.539 & 0.388 & 0.643 & 0.420 \\
\hline & ROA & 0.553 & 0.383 & 0.538 & 0.353 & 0.574 & 0.348 \\
\hline & ROA \& TA & 0.501 & 0.361 & 0.513 & 0.345 & 0.574 & 0.342 \\
\hline \multirow{4}{*}{$\begin{array}{c}1997 \\
(1122)\end{array}$} & Market & 0.501 & 0.353 & 0.493 & 0.370 & 0.553 & 0.373 \\
\hline & Industry & 0.532 & 0.398 & 0.515 & 0.387 & 0.573 & 0.386 \\
\hline & ROA & 0.529 & 0.357 & 0.498 & 0.334 & 0.522 & 0.338 \\
\hline & ROA \& TA & 0.506 & 0.350 & 0.493 & 0.346 & 0.514 & 0.338 \\
\hline \multirow{4}{*}{$\begin{array}{c}1998 \\
(1448)\end{array}$} & Market & 0.526 & 0.395 & 0.508 & 0.394 & 0.507 & 0.398 \\
\hline & Industry & 0.557 & 0.398 & 0.527 & 0.400 & 0.526 & 0.411 \\
\hline & ROA & 0.575 & 0.404 & 0.516 & 0.380 & 0.494 & 0.413 \\
\hline & ROA \& TA & 0.559 & 0.391 & 0.496 & 0.377 & 0.487 & 0.409 \\
\hline \multirow{4}{*}{$\begin{array}{c}1999 \\
(1584)\end{array}$} & Market & 0.546 & 0.433 & 0.566 & 0.452 & 0.607 & 0.455 \\
\hline & Industry & 0.549 & 0.411 & 0.550 & 0.427 & 0.593 & 0.434 \\
\hline & ROA & 0.562 & 0.395 & 0.558 & 0.411 & 0.546 & 0.408 \\
\hline & ROA \& TA & 0.539 & 0.387 & 0.539 & 0.408 & 0.533 & 0.396 \\
\hline \multirow{4}{*}{$\begin{array}{c}2000 \\
(1642)\end{array}$} & Market & 0.596 & 0.464 & 0.597 & 0.478 & 0.584 & 0.483 \\
\hline & Industry & 0.633 & 0.460 & 0.627 & 0.475 & 0.592 & 0.471 \\
\hline & ROA & 0.648 & 0.451 & 0.585 & 0.426 & 0.542 & 0.444 \\
\hline & ROA \& TA & 0.596 & 0.423 & 0.570 & 0.424 & 0.537 & 0.432 \\
\hline \multirow{4}{*}{$\begin{array}{c}2001 \\
(1634)\end{array}$} & Market & 0.554 & 0.429 & 0.562 & 0.429 & 0.553 & 0.431 \\
\hline & Industry & 0.563 & 0.401 & 0.578 & 0.418 & 0.564 & 0.419 \\
\hline & ROA & 0.565 & 0.398 & 0.528 & 0.376 & 0.490 & 0.388 \\
\hline & ROA \& TA & 0.546 & 0.401 & 0.518 & 0.375 & 0.495 & 0.394 \\
\hline \multirow{4}{*}{$\begin{array}{c}2002 \\
(1619)\end{array}$} & Market & 0.550 & 0.421 & 0.563 & 0.418 & 0.543 & 0.422 \\
\hline & Industry & 0.577 & 0.416 & 0.590 & 0.424 & 0.571 & 0.420 \\
\hline & ROA & 0.541 & 0.379 & 0.526 & 0.351 & 0.484 & 0.385 \\
\hline & ROA \& TA & 0.536 & 0.371 & 0.509 & 0.352 & 0.485 & 0.385 \\
\hline
\end{tabular}


Figure 1: Median absolute prediction error for the USA

This plot displays the median absolute prediction error for the USA when comparables are chosen from the US with the INDUSTRY, the ROA or with the ROA \& TA selection rule.

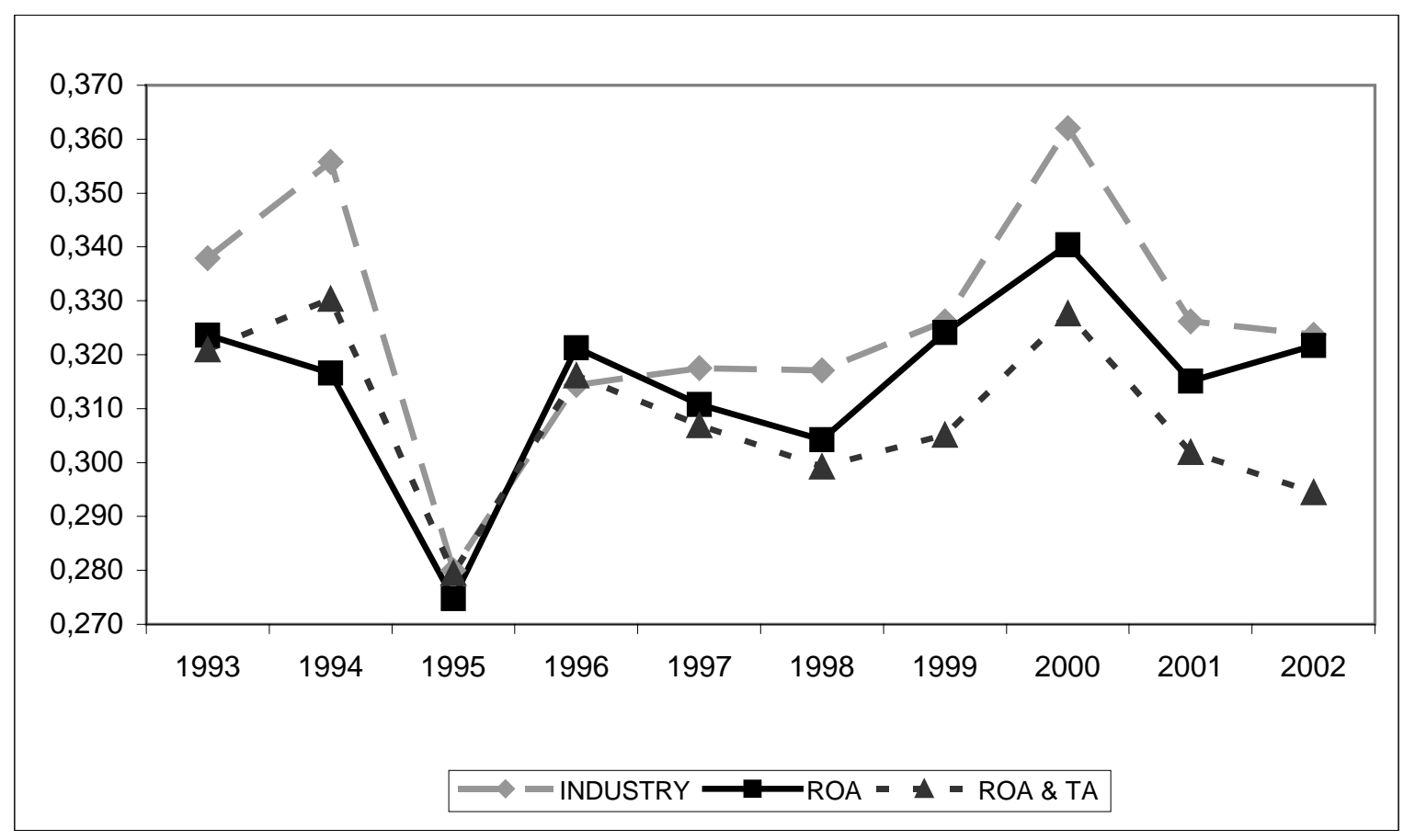

Figure 2: Median absolute prediction error for the UK

This plot displays the median absolute prediction error for the United Kingdom when comparables are chosen from the UK with the INDUSTRY, the ROA or with the ROA \& TA selection rule.

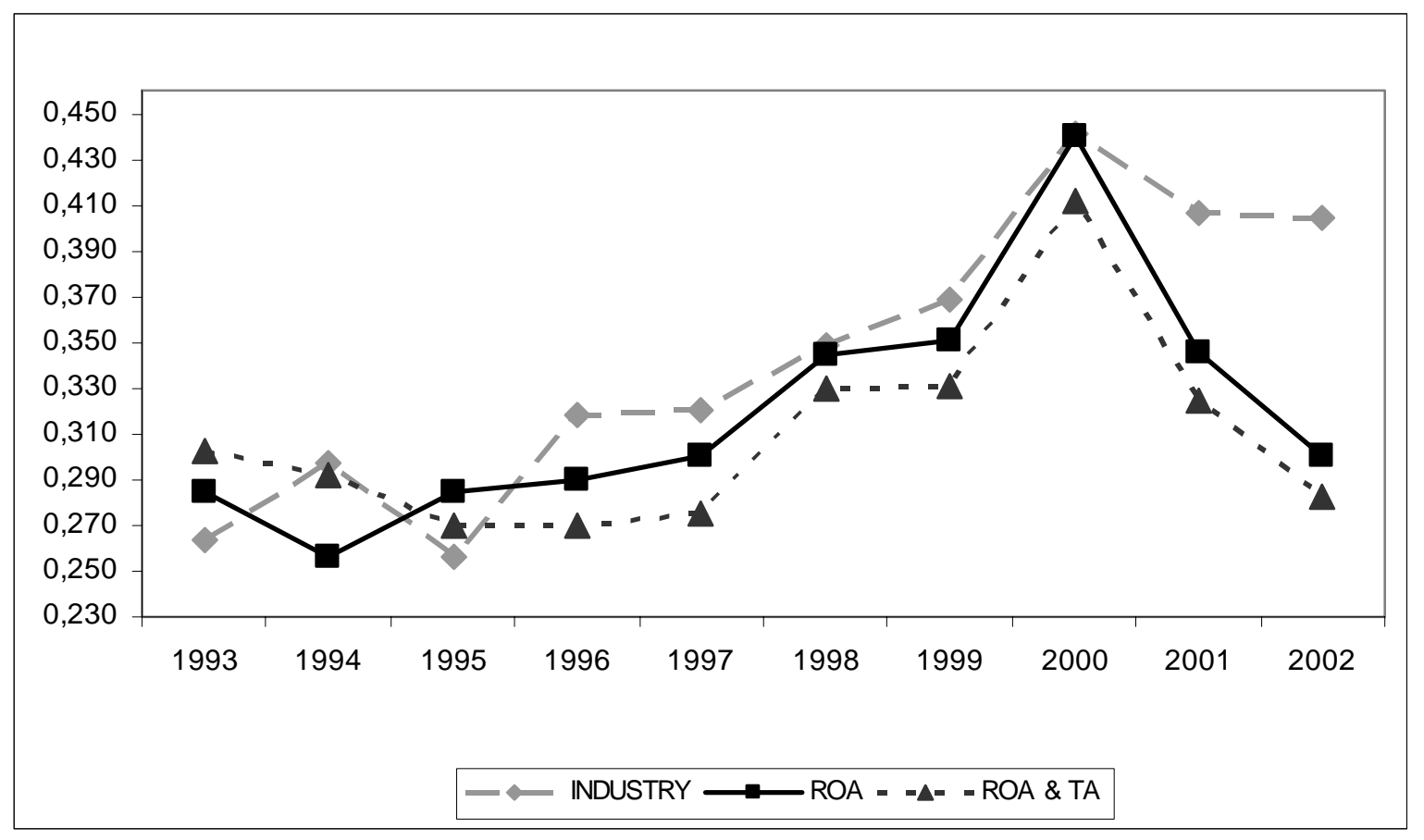


Figure 3:

Median absolute prediction error for the EU 15 without the UK

This plot displays the median absolute prediction error for the 14 European Union member states without the United Kingdom when comparables are chosen from the EU 15 with the INDUSTRY, the ROA or with the ROA \& TA selection rule.

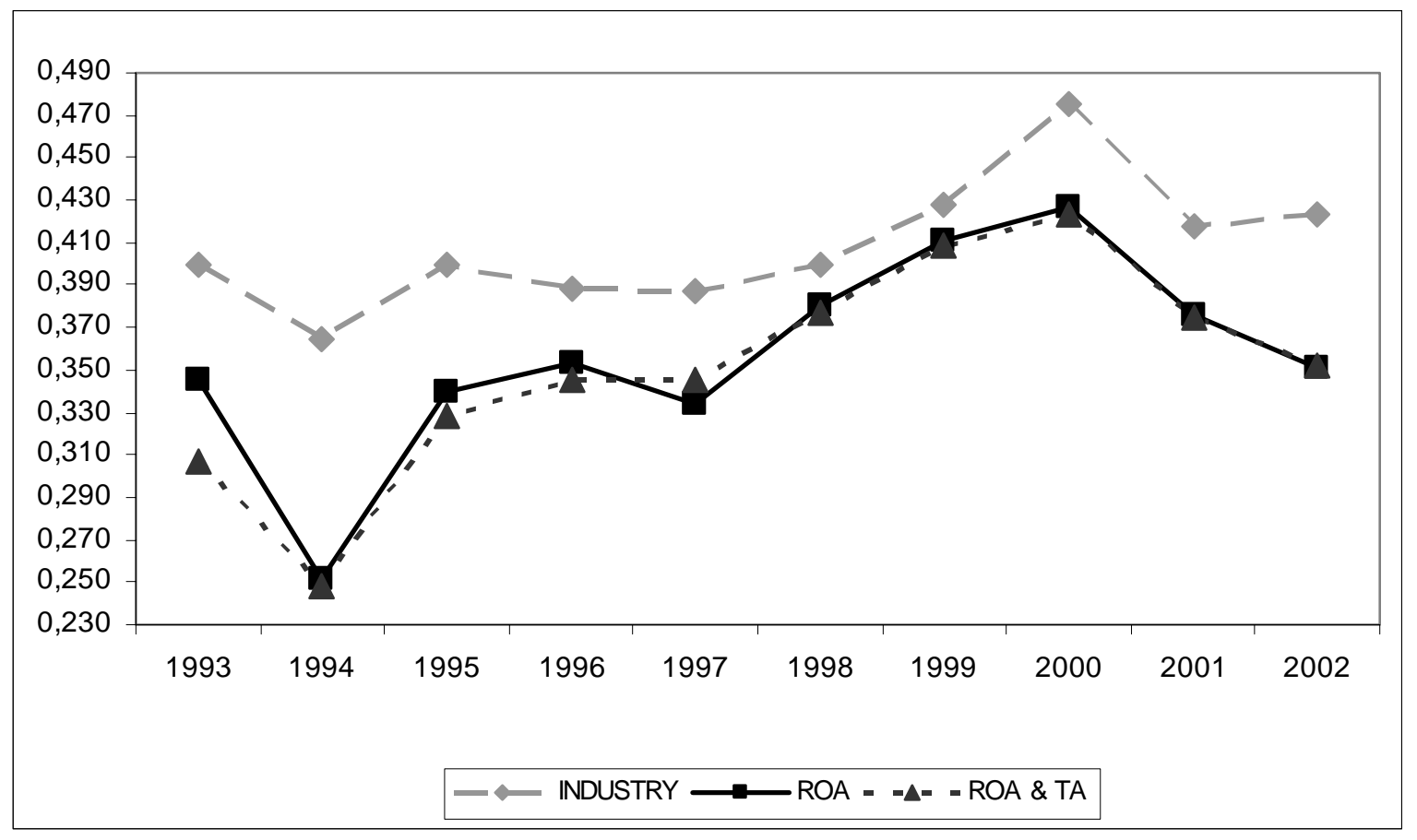




\section{SFB 649 Discussion Paper Series}

For a complete list of Discussion Papers published by the SFB 649, please visit http://sfb649. wiwi. hu-berlin.de.

001 "Nonparametric Risk Management with Generalized Hyperbolic Distributions" by Ying Chen, Wolfgang Härdle and Seok-Oh J eong, January 2005.

002 "Selecting Comparables for the Valuation of the European Firms" by Ingolf Dittmann and Christian Weiner, February 2005.

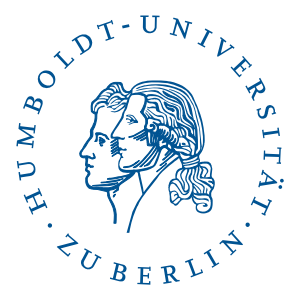

